\title{
Efficacy of three methods used to control staphylococcal mastitis in dairy goats
}

\section{Eficácia de três métodos empregados no controle da mastite estafilocócica em cabras leiteiras}

\author{
José Américo Barros Leite ${ }^{1}$; Renata de Moraes Peixoto Araújo ${ }^{2}$; Rodolfo de \\ Moraes Peixoto $^{3 *}$; Daniel Maia Nogueira ${ }^{4}$, Mateus Matiuzzi da Costa ${ }^{5}$
}

\section{Highlights:}

High efficacy of cloxacillin in dairy goats with subclinical mastitis.

Low effectiveness of staph vaccine in dairy goats.

Potentiation of antibiotic therapy associated with vaccination.

\begin{abstract}
Goat and sheep farming in Brazil relies on an expressive herd, especially in the Northeast region of the country, where small ruminants constitute a relevant economic activity, with milk production being an important source of income in some dry areas of the Northeastern states. However, there are still some sanitary problems in the management of dairy goats, among which mastitis is highlighted, especially that of the subclinical type. Therefore, the aim of this study was to evaluate the use of antibiotics, exclusively or in combination with vaccines, in the control of sub-clinical mastitis in small ruminants. The study was conducted on a rural property located in Santa Maria da Boa Vista-PE. Fifty-three female Saanen dairy goats were allocated into four experimental groups. An antibiotic therapy with a commercial antimicrobial based on cloxacillin was used in group 1. Group 2 received the commercial vaccine indicated for herds with an incidence of Staphylococcus strains and the same antibiotic described for Group 1. Group 3 was evaluated for the exclusive use of vaccination, and Group 4 was the control group. A microbiological examination of the milk was carried out to confirm cases of mastitis. The percentage of udders, infected by coagulase-negative Staphylococcus spp. (CNS) before and after the antibiotic + vaccine treatment was 42.8 and $7.1 \%$, respectively. It was observed that the cloxacillinbased antibiotic could be used alone or in combination with mastitis vaccines to control staphylococcal mastitis in small ruminants. Vaccination alone was not effective in reducing the number of mastitis cases; therefore, a cross reaction against CNS was not observed. Thus, further studies to determine the potential of vaccines to control sub-clinical mastitis in small ruminants are necessary.
\end{abstract}

Key words: Antibiotic therapy. Goats. Immunotherapy. Mastitis.

1 Discente do Curso de Pós-Graduação em Extensão Rural, Mestrado, Universidade Federal do Vale do São Francisco, UNIVASF, Petrolina, PE, Brasil. E-mail: mecoleite@gmail.com

2 Discente do Curso de Pós-Graduação em Ciência e Saúde Animal, Doutorado, Universidade Federal de Campina Grande, UFCG, Patos, PB, Brasil. E-mail: renatavet peixoto@hotmail.com

3 Prof. Dr., Instituto Federal de Educação do Sertão Pernambucano, IF SERTÃO, PE, Petrolina, PE, Brasil. E-mail: rmpeixoto. vet@gmail.com

4 Pesquisador, Embrapa Semiárido, Petrolina, PE, Brasil. E-mail: daniel.nogueira@embrapa.br

5 Prof. Dr., Colegiado de Zootecnia, UNIVASF, Petrolina, PE, Brasil. E-mail: mmatiuzzi@hotmail.com

* Author for correspondence

Received: Nov. 27, 2019 - Approved: Apr. 13, 2020 


\section{Resumo}

A caprinovinocultura brasileira dispõe de um expressivo rebanho, principalmente na região Nordeste do país, onde os pequenos ruminantes constituem uma relevante atividade econômica sendo a produção de leite uma importante fonte renda em algumas zonas secas dos estados do Nordeste. No entanto, ainda existem alguns problemas de ordem sanitária no manejo de cabras leiteiras, dentre esses, tem-se a mastite, principalmente aquela do tipo subclínica. Portanto, objetivou-se com este trabalho avaliar o uso isolado ou combinação de antibióticos e vacinas no controle da mastite em pequenos ruminantes. O estudo foi realizado em uma propriedade localizada no município de Santa Maria da Boa Vista - PE. Um total de 53 fêmeas leiteiras Saanen foram divididas em quatros grupos experimentais. No grupo 01 foi utilizada a antibioticoterapia, com antimicrobiano comercial a base de cloxacilina. O grupo 02 recebeu vacina comercial indicada para rebanhos com incidência de cepas do gênero Staphylococcus e o mesmo antibiótico descrito para o grupo 01. Em um terceiro grupo apenas a vacina foi empregada, e por último, foi constituído um grupo controle. Empregou-se o exame microbiológico do leite para confirmação dos casos de mastite. A porcentagem de tetos infectados por Staphylococcus coagulase negativa (SCN) antes e após o tratamento Antibiótico + Vacina foi de 42,8 e 7,1\%, respectivamente. Observou-se que o antibiótico a base de cloxacilina pode ser usado isoladamente ou em associação a vacinas anti-mastíticas para controle da mastite estafilocócica em pequenos ruminantes. O tratamento que preconizava a aplicação apenas da vacina não foi eficiente na redução dos casos da doença, portanto, não foi observada uma reação cruzada contra os SCN. Assim, faz-se necessária a continuidade dos estudos acerca do potencial das vacinas para o controle da mastite em pequenos ruminantes.

Palavras-chave: Antibioticoterapia. Caprino. Imunoterapia. Mastite.

Mastitis is an infection of the mammary gland, generally caused by bacteria, classified as clinical, sub-clinical, and chronic(Spuria etal., 2017). Mastitis is a major problem in dairy goats and due to its high prevalence, it causes problems for the dairy industry, generating negative impact on milk production and therefore resulting in economic losses (Alnakip et al., 2014). Pathogens of the genus Staphylococcus are most often found in intramammary infections in goats. The species Staphylococcus aureus is considered the most important among the species of the genus Staphylococcus, especially regarding public health. However, coagulase-negative Staphylococcus bacteria are the most prevalent in cases of subclinical mastitis in goats. A study points out that the prevalence of subclinical mastitis in goats can vary from 11.49 to $30.7 \%$ in the Brazilian Northeast region (Acosta, Silva, Medeiros, Pinheiro, \& Mota, 2016).

The control of this illness depends on preventive practices, which is why it is important to increase the response capacity of the animal's immune system through vaccination. It is worth reminding that the use of conventional antimicrobials alone has undesirable consequences for dairy production, among them the possibility of residues in the milk. Furthermore, the indiscriminate use of antimicrobial agents limits the therapy due to the emergence of resistant bacteria. Thus, in some herds, vaccination may be an alternative for the strategic control program of this infirmity (Vargas et al., 2016).

Among the practices currently indicated to minimize the economic impact of this disease, are early infection diagnosis, immediate treatment with commercial antimicrobials after conducting in vitro sensitivity tests, and the use of commercial vaccines, regardless of their demonstrated effectiveness. Due to the limitations of breeding programs, including the selection and genetic improvement of herds in order to improve the resistance against infectious diseases, such as mastitis, it is imperative to avail of an effective broad-spectrum vaccine, preferably with cross-protection, capable of protecting against the disease of complex etiology and reducing its incidence, as well as interrupting the potential transmission of species to humans (Tiwari et al., 
2013). It is also important to highlight the possibility of enhancing antibiotic therapy associated with vaccination (Vaz, Paterno, \& Marca, 2001).

There are few studies aimed at evaluating new strategies for the control of mastitis in herds of dairy goats, especially involving the evaluation of immunobiologicals. Therefore, the present work aimed to test the isolated or combined use of antibiotics and vaccines for controlling sub-clinical mastitis in dairy goats, and to verify the possibility of cross-reactions between Staphylococcus aureus and CNS species, relevant in caprine mastitis.

The study was carried out at a rural property, located in the municipality of Santa Maria da Boa Vista, Pernambuco state $\left(8^{\circ} 48^{\prime} 00^{\prime \prime} \mathrm{S}, 39^{\circ} 49^{\prime} 12^{\prime \prime}\right.$ $\mathrm{W})$. Average annual rainfall in the region is about $463.10 \mathrm{~mm}$, and mean temperatures are about $25.5^{\circ} \mathrm{C}$.

All experiments involving animals (Capra hircus) followed the standards established by the Brazilian Director for the care and use of animals for scientific and didactic purposes. The experiment was conducted in a private dairy goat property. The milking was manually performed on a platform, with the pre-dipping being performed with a chlorinated solution and the post-dipping with an iodine-based solution. In the mornings, the animals were maintained in a rotational grazing system in paddocks with irrigated Tanzania grass (Panicum maximum cv. Tanzânia). In the afternoons, they were moved to the goat barn and offered Elephant grass (Pennisetum purpureum Schum.) for bulky feed, along with feed concentrate with $16 \%$ crude protein, as well as water and mineral supplementation ad libitum.

The herd ( $\mathrm{n}=84$ goats) presented a frequency of $23.8 \%$ for subclinical mastitis and history of CNS isolation (Andrade, Peixoto, Nogueira, Krewer, \& Costa, 2012). A total of 53 Saanen females in the final stage of lactation, with age varying between two and four years and with similar conditions of body condition score, were divided into four experimental groups. The females were distributed into four experimental groups by means of a draw and, in each group, there were animals with and without the disease, with equally proportional numbers. For Group $1(\mathrm{n}=13)$, a commercial antimicrobial based on cloxacillin was administered (200 mg). Group $2(n=14)$, received a commercial staphylococcal vaccine $($ Mastaph $\AA)$ and the same antimicrobial used in the previously mentioned group. Both were administered at the same experimental moment. In Group 3 ( $n=11$ ) only the vaccine was administered, whereas the last group constituted a control $(n=15)$.

The vaccination protocol followed the guidelines of the Mastaph ${ }^{\circledR}$ vaccine manufacturer. It is an immunobiological indicated for the control of staphylococcal mastitis in cattle herds, containing a capsulated S. aureus strain. Two applications were performed at a 21-day interval, during the lactation period. The dose of $0.5 \mathrm{~mL}$ was adjusted for the goat species via subcutaneous application.

To confirm cases of mastitis, a microbiological examination of the milk was performed three times, two after the second dose of the vaccine. The samples were collected in the morning, after the pre-milking udder hygiene procedure, such as washing of teats with chlorinated water and drying with paper towel. The samples were milked directly into previously identified, sterile vials, which were kept in isothermal boxes with ice and immediately taken to the laboratory for processing.

Volumes of $10 \mu 1$ from each sample were sowed with a calibrated loop in each quadrant of a Blood Agar Base plate added by 5\% of defibrinated sheep blood. Thus, the plaques that presented a hemolytic colony and/or those containing four non-hemolytic colonies or more, with the same morphological characteristics, were considered positive. For the identification of the isolates belonging to the genus Staphylococcus, biochemical tests for coagulase, DNAse, use of semi-solid glucose, and semi-solid mannitol were performed, in addition to the purple agar base, esculin and urease mediums (Holt, 1994).

The susceptibility profile of the microorganisms was determined by a modified Kirby-Bauer disc 
diffusion method. Antimicrobial drugs: tetracycline $(30 \mu \mathrm{g})$, ciprofloxacin $(05 \mu \mathrm{g})$, gentamycin $(10 \mu \mathrm{g})$, ampicillin $(10 \mu \mathrm{g})$, norfloxacin $(10 \mu \mathrm{g})$, oxacillin $(01 \mu \mathrm{g})$, ceftriaxone $(30 \mu \mathrm{g})$, lincomycin $(02 \mu \mathrm{g})$, nitrofurantoin $(300 \mu \mathrm{g})$, sulfamethoxazole $(25 \mu \mathrm{g})$, neomycin $(30 \mu \mathrm{g})$ penicillin $\mathrm{G}(10 \mathrm{U})$. The test was performed according to the standard protocol (Clinical and Laboratory Standards Institute [CLSI], 2015).

To assess the association between positive mastitis results before and after the applied treatments, a chi-square test was performed, with $\mathrm{P}<0.05$ considered to be statistically significant. Statistical data analysis was conducted using the Statistical Package for the Social Sciences version 20.0 for Windows.

In the lacto cultures, a positivity rate of $47.2 \%$ was observed among 53 animals from which samples were collected, the etiological agent being CNS. As for the amount of infected udder halves, a positivity rate of $32.1 \%$ was observed in a total of 106 collected samples. This result is in consonance with the scientific literature since it demonstrates that the CNS are the most commonly isolated agents in herds of dairy goats. Coagulase-negative Staphylococcus (CNS) can also cause clinical and sub-clinical mastitis, along with a significant increase in somatic cell count in the milk. The importance and pathogenicity of CNS species vary broadly. For goats, $S$. epidermidis tends to be the most frequently isolated one, followed by $S$. caprae, which in some studies was reported to be the most predominant species (Kautz, Nickerson, \& Ely, 2014; D’ersu et al., 2016).

During antimicrobial susceptibility testing, greatest sensitivity was observed for: ciprofloxacin and norfloxacin (100\%), followed by nitrofurantoin $(97,8 \%)$, ceftriaxone $(93,3 \%)$, oxacillin $(88,8 \%)$, gentamicin $(82,2 \%)$, sulfamethoxazole $(71,1 \%)$, neomycin $(66,6 \%)$ and lincomycin $(55,5 \%)$ (Figure $1)$. Based on these results and considering its availability on the market, cloxacillin - a derivative of oxacillin- was chosen for evaluation. A study by Moroni et al. (2005) showed the resistance of $S$. epidermidis isolates to amoxicillin, whereas the susceptibility to other beta-lactams (ampicillin and penicillin $G$ ) varied. The same authors reported low susceptibility to tetracycline, which was similar to that observed in the present study. Staphylococcus spp. isolates from mastitis in goats and sheep tend to be less resistant to antimicrobials (Contreras et al., 2007).

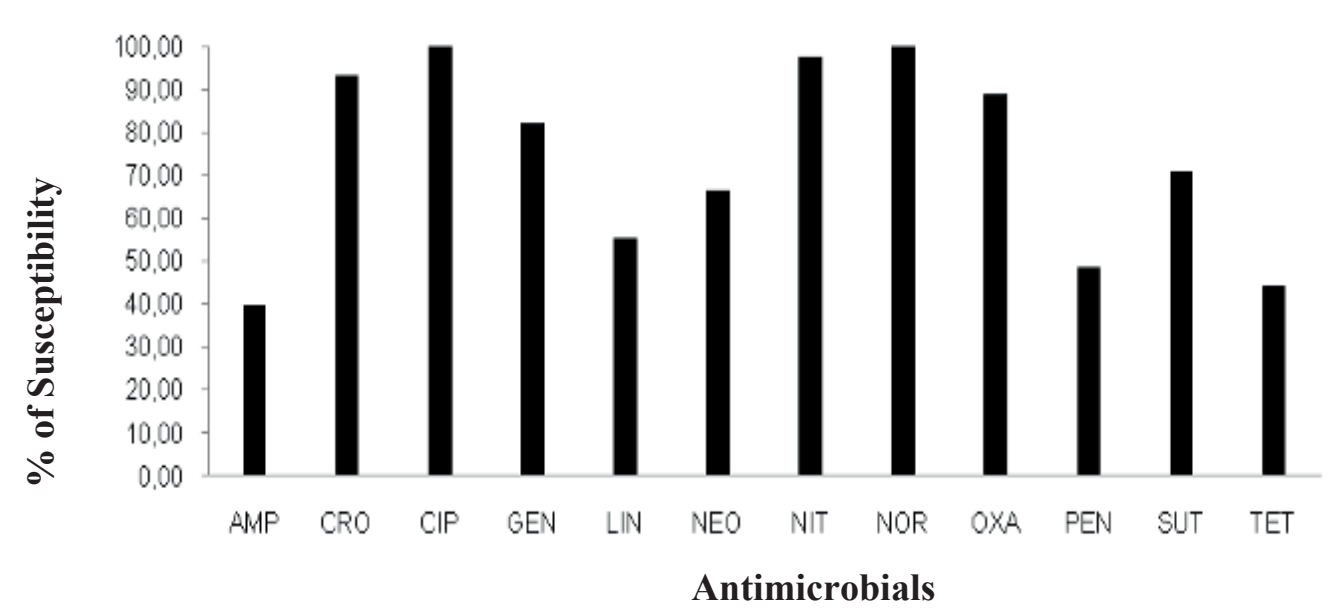

Figure 1. Susceptibility profile of antimicrobials of S. epidermitidis and S. caprae isolates obtained from dairy goats in Santa Maria da Boa Vista, Pernambuco state, 2007.

AMP (ampicillin); CRO (ceftriaxone); CIP (ciprofloxacin); GEN (gentamicin); LIN (lincomycin); NEO (neomycin); NIT (nitrofurantoin); NOR (norfloxacin); OXA (oxacillin); PEN (penicillin G); SUT (sulfamethoxazole); TET (tetracycline). 
Theexclusiveuse of cloxacillinas an antimicrobial in the antibiotic group was efficient in reducing the infection rate significantly $(P<0.05)$. No grupo dois, a associação do antimicrobiano e vacina também proporcionou uma redução no número de casos de mastite de 42.8 para $7.1 \%(P<0.05)$. Researchers have shown a potentiation of the antibiotic therapy combined with vaccination, increasing the cure rates from $20-30 \%$ to $70-80 \%$ (Vaz et al., 2001). It is worth noting that the treatment with antibiotics requires veterinary monitoring in order to guarantee appropriate and hygienic delivery. Several outbreaks have been attributed to iatrogenic effects, due to the use of syringes contaminated with Pseudomonas aeruginosa or Aspergillus fumigatus (Bergonier, Cremoux, Rupp, Lagriffoul, \& Berthelot, 2003).

Regarding group 3, it was observed that the exclusive use of vaccination was not efficient in controlling staphylococcal mastitis in small ruminants. When solely using vaccination, it was observed that the number of mastitis cases increased significantly $(P<0.05)$ from 9.15 to
$40.95 \%$ (Table 1). The vaccine used in the present study is indicated for prevention of mastitis caused by $S$. aureus, and a cross reaction was expected, with a consequential immunogenic action in herds with CNS. This result differs from that observed by Schukken et al. (2014), who observed a lower rate of new CNS infections after immunization with a commercial vaccine containing $S$. aureus antigens. Moreover, the authors observed that vaccination reduced the basic number of disease reproduction (R0) by approximately $45 \%$ in S. aureus and 35\% in CNS. The cure rate was $45 \%$ for S. aureus and $16 \%$ for CNS. Although these authors used a strain of $S$. aureus, the main antigens were different from those found in the vaccine used in our study. The authors also used the bovine species, and this may explain the difference in the results obtained between the studies regarding the effectiveness of the vaccine. Furthermore, there is a long monitoring period of the animals and an expressive number of females allocated to the control and vaccine groups, characterizing distinct experimental designs.

Table 1

Percentage of udders infected by coagulase-negative Staphylococcus spp., before and mastitis control in dairy goats, in the municipality of Santa Maria da Boa Vista, Pernambuco state

\begin{tabular}{cccccc}
\hline \multirow{2}{*}{ Treatment } & \multicolumn{5}{c}{ Percentage of udders infected by coagulase-negative Staphylococcus spp. } \\
\cline { 2 - 6 } & Total (n) & \% Before (n) & \% After (n) & $\boldsymbol{X}^{2}$ & P \\
\hline Antibiotic & 26 & $42.3(11)^{\mathrm{a}}$ & $7.7(2)^{\mathrm{b}}$ & 6.55 & $\mathrm{P}=0.010$ \\
Antibiotic + Vaccine & 28 & $42.8(12)^{\mathrm{a}}$ & $7.1(2)^{\mathrm{b}}$ & 7.71 & $\mathrm{P}=0.005$ \\
Vaccine & 22 & $9.1(2)^{\mathrm{a}}$ & $40.9(9)^{\mathrm{b}}$ & 4.36 & $\mathrm{P}=0.036$ \\
Control & 30 & $30.0(9)$ & $20.0(6)$ & 0.35 & $\mathrm{P}=0.550$ \\
\hline
\end{tabular}

${ }^{\mathrm{a}, \mathrm{b}}$ Different superscript letters in the same line refer to difference in Chi-square.

Kautz et al. (2014) conducted a study to assess the effectiveness of a bacterin in reducing the prevalence of staphylococcal mastitis and somatic cell count (SCC) in a herd of dairy goats monitored over 18 months. The infection rate was 1.64 /goat among those vaccinated, with a tendency to be lower $(\mathrm{P}<0.12)$ than in the control group, which had an infection rate of $2.67 /$ goat. The rate of spontaneous cure after immunization was 1.28 among vaccinated females and 0.6 for the control group $(\mathrm{P}<0.043)$. The findings reinforce the need for further studies involving the production of vaccines to control staphylococcal mastitis in dairy goats. 
Besides presenting several risk factors, mastitis is an infirmity of complex etiology, with several potential pathogens. This characteristic makes the production of immunobiologicals difficult given the diversity of agents involved in cases of clinical and subclinical mastitis in goats. For Tiwari et al. (2013) it is important to produce broad-spectrum vaccines, with cross-protection for different pathogens in order to reduce the incidence of the disease. The authors also claim that studies have shown promising results However, in some cases, their effectiveness has not been evaluated under field conditions. Thus, the development of vaccines with proven efficacy in the field constitutes an arduous task and requires a large investment in $\mathrm{P} \& \mathrm{D}$.

With regard to the economic benefit, the implementation of antimicrobial therapy in the dry period, associated with vaccination, can reduce the number of antimicrobials needed for the treatment of bovine mastitis, resulting in a smaller number of days in which milk is discarded (Vargas et al., 2016). According to Contreras et al. (2007), additional studies on immunization are required to improve this strategy. Likewise, further studies should be conducted for goat herds where $S$. aureus is not the main etiological agent of mastitis.

In this study, the significant reduction in coagulase-negative Staphylococcus spp. infected udders was probably obtained exclusively due to the action of the antimicrobial cloxacillin, and not as a result of the combined antibiotics/vaccine treatment, thus demonstrating the absence of a cross reaction of the $S$. aureus vaccine, and therefore the inability to induce immunity in herds with CNS. Nevertheless, the continuity of studies for the potential of vaccines for mastitis control in small ruminants is imperative.

\section{References}

Acosta, A. T., Silva, L. B. G., Medeiros, E. S., Pinheiro, J. W., Jr., \& Mota, R. A. (2016). Mastites em pequenos ruminantes no Brasil. Pesquisa Veterinária
Brasileira, 36(7), 565-573. doi: 10.1590/S0100736X2016000700001

Alnakip, M. E., Quintela-Baluja, M., Böhme, K., Fernández-No, I., Caamaño-Antelo, S., Calo-Mata, P., \& Barros-Velázquez, J. (2014). The immunology of mammary gland of dairy ruminants between healthy and inflammatory conditions. Journal of Veterinary Medicine, 2014(10), 1-31. doi: 10.1155/2014/65 9801

Andrade, N. P. C., Peixoto, R. M., Nogueira, D. M., Krewer, C. C., \& Costa, M. M. (2012). Perfil de sensibilidade aos antimicrobianos de Staphylococcus spp. coagulase negativa de um rebanho leiteiro caprino em Santa Maria da Boa Vista - PE. Medicina Veterinária, 6(1), 1-6.

Bergonier, D., Cremoux, R., Rupp, R., Lagriffoul, G., \& Berthelot, X. (2003). Mastitis of dairy small ruminants. Veterinary Research, 34(5), 689-716. doi: 10.1051/vetres:2003030

Clinical and Laboratory Standards Institute (2015). Performance standards for antimicrobial disk and dilution susceptibility test for bacteria isolated from animals; approved standard. CLSI document M31-A3 (3nd ed.). Wayne: Clinical and Laboratory Standards Institute.

Contreras, A., Sierra, D., Sánchez, A., Corrales, J. C., Marco, J. C., Paape, M. J., \& Gonzalo, C. (2007). Mastitis in small ruminants. Small Ruminant Research, 68(1-2), 145-153. doi: 10.1016/j. smallrumres. 2006.09.011

D'ersu, J., Aubin, G. G., Mercier, P., Nicollet, P., Bémer, P., \& Corvec, S. (2016). Characterization of Staphylococcus caprae clinical isolates involved in human bone and joint infections, compared with goat mastitis isolates. Journal of Clinical Microbiology, 54(1), 106-113. doi: 10.1128/JCM.01696-15

Holt, J. G. (1994). Bergey's manual of determinative bacteriology. Baltimore, MD: Williams and Wilkins.

Kautz, F. M., Nickerson, S. C., \& Ely, L. O. (2014). Use of a staphylococcal vaccine to reduce prevalence of mastitis and lower somatic cell counts in a registered Saanen dairy goat herd. Research in Veterinary Science, 97(1), 18-19. doi: 10.1016/j. rvsc. 2014.04 .013

Moroni, P., Pisoni, G., Antonini, M., Ruffo, G., Carli, S., Varisco, G., \& Boettcher, P. (2005). Subclinical mastitis and antimicrobial susceptibility of Staphylococcus caprae and Staphyloccoccus epidermidis isolated from two Italian Herds. Journal of Dairy Science, 88(5), 1694-1704. doi: 10.3168/ jds.S0022-0302(05)72841-1 
Schukken, Y. H., Bronzo, V., Locatelli, C., Pollera, C., Rota, N., Casula, A., \& Moroni, P. (2014). Efficacy of vaccination on Staphylococcus aureus and coagulase-negative staphylococci intramammary infection dynamics in 2 dairy herds. Journal of Dairy Science, 97(8), 5250-5264. doi: 10.3168/jds.20148008

Spuria, L., Biasibetti, E., Bisanzio, D., Biasato, I., Meneghi, D. de, Nebbia, P., \& Capucchio, M. T. (2017). Microbial agents in macroscopically healthy mammary gland tissues of small ruminants. PeerJ, 5, 1-18. doi: 10.7717/peerj.3994/supp-1

Tiwari, J., Babra, C., Tiwari, H. K., Williams, V., De Wet, S., Gibson, J., Mukkur, T. (2013). Trends in therapeutic and prevention strategies for management of bovine mastitis: an overview. Journal of Vaccines \& Vaccination, 4(2), 1-11. doi: 10.4172/21577560.1000176
Vargas, R. T., Souza, F. N., Brito, M. A. V. P., Brito, J. R. F., Leite, M. O., Fonseca, L. M., \& Cerqueira, M. O. P. (2016). Partial budget analysis of prepartum antimicrobial therapy and Escherichia coli J5 vaccination of dairy heifers and their effect on milk production and milk quality parameters. Pesquisa Veterinária Brasileira, 36(2), 77-82. doi: 10.1590/ S0100-736X2016000200003

Vaz, A. K., Paterno, M. R., \& Marca, A. (2001). Avaliação da vacina estafilocócica como auxílio à antibioticoterapia de mastite subclínica durante a lactação. A Hora Veterinária, 21(124), 68-70. 
